\title{
Four Second Graders' Descriptions of How They Spell
}

\author{
SUZANNE LANGFORD \\ University of Redlands
}

\author{
MARY NEAL \\ Cutten School District
}

The purpose of this study is to learn more about the spelling knowledge of belowaverage and above-average second grade spellers. Four questions guide the research: (1) Do second graders' descriptions of their spelling knowledge reflect the developmental stages that their written spellings suggest? (2) Do below-average and above-average second grade spellers describe their spelling knowledge differently? (3) Is spelling knowledge task specific? Does a child describe one kind of spelling knowledge for a qualitative spelling inventory that is an assessment of stage development, and another kind for an informal writing activity that does not involve assessment? (4) Does invented spelling instruction in first grade influence second grade spelling knowledge?

Approaches to Spelling

There is more than one approach to the teaching of spelling. In addition to traditional and structured language approaches, there is a developmental approach (Schlagal, 2001). Briefly, the traditional approach accounts for two opposing views of the English-spelling system; one is that English is unpredictable and rote memorization is necessary and the other is that there are orthographic patterns that are generalizable. The structured language approach grew out of Samuel Orton's work with dyslexic readers. This approach focuses on accurate links between letters and sounds and uses direct teaching with visual and kinesthetic methods to link phonemic awareness, decoding, blending, and spelling. Often, instruction for students who struggle with reading focuses on the syllable and provides specific training in syllable types and syllable division.

In a developmental approach to spelling, written word knowledge and the way it develops in spelling is seen as important for understanding related literacy processes such as phonemic awareness, phonics, and writing. This is because stages of spelling development are understood to demonstrate the growth of students' knowledge about features and regularities of the English-spelling system (Henderson, 1981). Most children develop through a sequence of spelling strategies and their spelling competence 
increases developmentally; however, they may display a range of spelling abilities at any age (Gentry, 2000).

Although researchers may disagree on labels, there is general agreement that there are six spelling stages: preliterate, early- and late-letter-name, within word, syllable juncture and derivational constancy. Children in the preliterate stage are not yet phonemically aware, that is, they do not know that speech sounds are represented by written symbols. As children's awareness develops their writing progresses from scribbling to mock linear writing to random letters and numbers. In the early letter-name stage, children begin to recognize the relationships between sounds and letters. In writing, they begin to develop a concept of word and use letters to represent important sounds in syllables and words (e.g., $K K$ for cake, $J G N$ for dragon, and $B D$ for bead). Letter-name spellers generally do not represent silent letters or nasals before a consonant (e.g., $[\mathrm{m}]$ in bump); and they often replace a standard spelling short vowel letter with the long vowel letter name that "feels" most similar as they form it in the vocal tract (where articulation occurs) (e.g., nat for net; fes for fish). In the late letter-name stage, a stable concept of word is developed and children can spell phonetically any word they can speak by using direct letter-to-sound matches. Their knowledge of consonant sounds, consonant blends and digraphs, and long and short vowel sounds is developing. When children internalize the sound-symbol relationships of consonants, consonant blends and digraphs, and long and short vowels, they can focus on common patterns of letters found within words such as, correct representations of short vowels and variations in representing the marking system in long vowels (e.g., rain for rane, feed for feide). This is the within-word stage of spelling development. During the syllable-juncture stage, children focus on patterns across syllable boundaries and begin to correct errors in multisyllabic words at the point where the syllables join (e.g., hopping for hoping, diresctsion for direction). The derivational constancy stage begins as students honor the preservation of meaning through spelling patterns in related words such as sign, signal, and signature. Errors often result when the writer spells the word as it sounds (e.g., conpatition for competition) (Henderson, 1990).

Children regularly invent spellings for words that they do not know how to spell conventionally. These spellings have errors of substitution and omission that are consistent and do not happen by chance. They show a hierarchy of articulatory features and the speller's concept of how words should be represented by letters changes developmentally. Orthographic knowledge develops as a process in children and their invented spelling reflects this development. There is evidence that children who invent spellings spend more time engaged in writing than those who use correct spelling; these creative writing activities especially help children at the beginning of first grade who have emerging alphabetic knowledge, spelling, and reading skills, to appreciate the alphabetic principle. Once they grasp this principle, invented spelling is no longer superior to traditional spelling (Clarke, 1988). Invented spellings, like miscues in reading, may provide opportunities for teachers to assess and teach not only spelling, but other elements of literacy including, phonemic awareness, phonics, and writing (Gentry, 2000).

It is important for teachers to observe early differences in students' literacy development. For example, it appears that above- and below-average spellers do not use similar processes in spelling (Lennox \& Siegel, 1998). Phonological skills are often deficient in below-average readers and spellers, but their visual memory skills are 
equivalent or better than in the average population. Above-average spellers, however, use both phonological and visual cues to a greater extent than do age matched below-average spellers. The role of the teacher in supporting students' developmental growth from invented to conventional spelling does not appear to be well understood:

The theoretical and descriptive research ... has been quite rich in describing what is happening cognitively as children learn to spell. What is still lacking is an equally rich articulation of what adults do that assists children's development. (Sipe, 2001, p. 4)

Perhaps one reason we know little about the teacher's role in supporting children's spelling development is because most spelling studies look at the product of children's spelling knowledge, that is, their written words. Few studies observe children in the process of spelling and writing tasks and listen to them talk about their orthographic knowledge (Dahl et al., 2003; Weiner, 1994; Wilde, 1986). This is a missed opportunity, as observing and communicating with young writers in the process of spelling can provide significant information for teachers and others interested in spelling assessment and instruction. This is because the resultant spelling knowledge represents an awareness of, attitude toward, and ability to engage in, the process of spelling (Weiner, 1994) which is integral to other literacy elements including phonemic awareness, phonics, and writing (Gentry, 2000). Understandings about students' spelling processes may provide teachers with insights about students' other literacy processes. To broaden a perspective of spelling that includes a description of the cognitive process, as teachers we must listen as students describe the ways in which they spell words. This study is just such an opportunity.

\section{METHOD}

\section{Students}

Four students (mean age, 7 years, 9 months), from the second author's second grade classroom, were participants in the study during the month of April. We considered the following when selecting participants: (1) teacher judgment determined that the participants were below-average and above-average spellers (in terms of spelling accuracy); (2) Betty and Kurt (all names are pseudonyms) were in the letter-name stage of spelling development, and Mark and Tammy were in the within-word stage of spelling development based on scores on the Johnson Developmental Spelling Test (Bear, Invernizzi, Johnston \& Templeton, 2000); (3) the students were willing to talk about their spelling (4); Betty (below-average) and Mark (above-average) had Ms. C for the entire year of first grade, while Kurt (below-average) and Tammy (above-average) had Ms. N; (5) none of the students had significant speech or hearing problems and (6) two boys and two girls ensured equal gender representation.

All four participants were native speakers of English. Their pre-school or home experiences are unknown. However, their first grade classroom literacy experiences were markedly different. Kurt and Tammy experienced writing workshop, which includes story planning, revision, and editing. They also used an Author's Chair to read their "published book" to their classmates. During writing workshop, Kurt and Tammy were 
encouraged to use invented spelling because the emphasis was on creative writing and thinking. They were urged to think about the sounds they heard in the word they wanted to spell and write them down. Mark and Betty did not have these experiences in first grade. They did not write stories because their teacher taught writing primarily through phonics worksheets or sentence prompts (in which the students wrote the ending for a sentence that the teacher started). Mark and Betty learned to ask their teacher or an adult for the correct spelling of a word or they used small, personal dictionaries to look up words they did not know how to spell. They did not share or read aloud written work to classmates.

\section{Data Collection}

Following parental permission to participate in the study, the second author conducted individual interviews with the participants in the school library during times when other students were not present. She asked the students if they would help her by demonstrating and talking about their spelling and writing. All students agreed. As the students spelled and wrote, they described their spelling and their verbalizations were audiotaped. Additional data includes: a written, twenty-word qualitative spelling inventory, and a writing sample.

\section{General}

\section{Setting}

The setting was a small, rural elementary school on the northwestern coast of the United States that serves families of lower to middle socio-economic status. At the time of this study and the three years preceding it, the school district did not endorse a specific language arts program for first grade. Administrators and teachers questioned which approach to teaching reading was most effective. They selected direct phonics instruction and decided to spend their language arts adoption money on sets of phonetic readers for their "book closet." The sets consisted of six to twelve copies of each book. The books were leveled from one to eighteen and there were approximately ten different books at each level. The first grade teachers checked the sets of books out to use with small ability-groups. The first grade did not adopt a formal spelling or writing program. Instead, the teachers individualized the language arts curriculum to meet their own instructional approaches to literacy instruction.

\section{Grade One Teachers}

Before entering the second author's grade two classroom, the study participants had either "Ms. Phonics" or "Ms. Invented Spelling" for first grade. Children from one of these two classrooms were selected, because out of the four grade one teachers in the school, these two teachers had contrasting views of spelling instruction and taught reading/language arts (which includes spelling) for a similar block of time (approximately 90 minutes) during the school day.

Ms. P's first grade classroom.

Ms. P had been teaching for over twenty-five years. Her early training and many years of teaching experience involved direct phonics instruction. In Ms. P's class, the approach to spelling was traditional and invented spelling was not taught, used, or 
encouraged. She emphasized word family instruction, used a phonics-based spelling program, and gave a formal weekly spelling test on Fridays. She did not believe in invented spelling and did not feel comfortable allowing her students to use it in their writing. Only correct spelling of words was allowed in their journal writing. Children were to look up the word or ask an adult how to spell each word correctly. Children wrote in their journals daily and each child had his/her own personal dictionary. Ms. P used many daily phonics worksheets that the children completed independently. She encouraged her students to use correct letter formation, write on the lines, and spell correctly on all class writing activities. Ms. P expressed that first-grade children should be taught the correct mechanics of writing. This is why she believed invented spelling was not helpful; she stated that her students' writing was better in mechanics and content without it. Ms. P also believed that developing phonological awareness in her first grade students was the key to future reading and spelling success. In addition to the sets of phonics readers, she used a commercial letter-sound program to promote this awareness. She gave a word orally and the students chose among selected letters and/or sounds, those that they heard in the given word. The students then wrote the word by writing the letters or sounds that they selected in sequence. Follow-up activities included spelling activities and phonics worksheets that the children completed independently.

Ms. I's first grade classroom.

Ms. I had two years of teaching experience and recent exposure to theory and practice of writing development in her teacher credential program at the local university. She conducted daily writer's workshops and let students select their own topics, because she believed this motivated them to complete texts to read to their classmates. She encouraged her students to use invented spelling and sound out words as they wrote, as she explained this allowed for more creative writing. She had a daily mini-lesson in which she met with children to discuss their story planning, revision, and editing, and she supplied an Author's Chair for students to read their "published books" to the class. Ms. I used "making words" (Cunningham, 2005) as her word study program. Children made 12-15 words beginning with two-letter and continuing with three-letter, four-letter, fiveletter and longer until the final big word was made. Making words is an active, hands-on manipulative activity in which children discover sound-letter relationships and learn how to look for patterns in words. To back-up her program, Ms. I cited research claiming that there is a strong correlation between spelling ability and the ability to decode words in reading. Ms. I believed that invented spelling and decoding were a mirror-like process that made use of the same store of phonological knowledge. In Ms. I's class, students received mini-lessons on invented spelling throughout the year. In the writer's workshop format they used invented spelling during all writing activities. A word wall was available and students were encouraged to discuss and help each other with spelling and writing. No formal spelling tests were given. Correct letter formation or writing letters on lines was not stressed and phonics worksheets were rarely assigned. Ms. I's goal was for children to communicate authentically and express themselves creatively. She believed de-emphasizing standard spelling would help her students accomplish this goal. Ms. I also believed in the importance of phonological awareness and learning letter-sound associations for success in reading and spelling. To accomplish this she too implemented 
a commercial program that used an integrated picture mnemonic strategy combined with a corresponding large body movement.

The grade two classroom.

The second author's grade 2 classroom, from which the participants were drawn, used a commercial language arts program that focused on phonics, word study, and fluency. In this program the teacher/second author embraced both developmental and traditional views of spelling and included these as integral parts of a balanced reading and writing program. Balance here means that although the commercial program was systematic in its scope and sequence, the instruction sought to engage students in meaningful reading and writing activities, and the teacher/second author held a "healthy skepticism toward the ... wholesale acceptance of prepackaged materials" (Heydon, Hibbert \& Iannacci, 2004-2005). Students in the classroom had opportunities to read, discuss, and write about texts to which they had a personal connection. The teacher/second author emphasized word family instruction and provided direct instruction in various word analysis activities such as, syllabication, affixes, root words, etc. Students participated in a variety of weekly writing activities that included a standard spelling pretest and test, journals, narrative and expository pieces, and poetry. In addition, invented spelling was not discouraged during creative writing and a word wall and individual dictionaries were available to help children spell words they did not know. The teacher/second author informally, but consistently, assessed her students' invented spellings for signs of development.

\section{Instrumentation}

Teaching spelling effectively requires understanding the process of thought that is revealed in children's spelling (Kress, 2000). Think-aloud or talk-aloud verbal reports can be a valuable and reliable source of information about many cognitive processes, including spelling (Ericsson \& Simon, 1980). In the current study, a "curious puppet" (Read, 1975) who wanted to learn to spell was placed on the child's pencil. The puppet was a small bumblebee called the "Spelling Bee."

The study explored the task specificity of the participants' spelling knowledge by using two spelling tasks: a qualitative spelling inventory (see Appendix A) and an informal writing activity. During the administration of the tasks, the child wrote the word or words and the puppet asked the student to "say out loud everything that you say to yourself in your head." Prompts were used such as, "why did you spell the word that way?" or "how did you figure out how to the spell that word?" The four students understood and accepted the talk-aloud task.

A qualitative spelling inventory identifies the word elements children have mastered and those currently under negotiation (Bear, Invernizzi, Johnston \& Templeton, 2000) and a child's score on a developmental spelling inventory is a powerful predictor of knowledge of regular phonics patterns (Gentry, 2000; Sipe, 2001) The spelling inventory consisted of twenty words (see Appendix A) and took approximately 30 minutes to administer.

The writing activity was an opportunity for the students to use writing for the purpose of communication, albeit the puppet's purpose, and to use a wider variety of words than those included on the qualitative spelling inventory. For purposes of data 
analysis, the activity also directed the students' spelling toward a common set of words. The child and the puppet used a colorful, detailed picture; a copy of an illustration from the book Jimmy's Boa and the Big Splash Birthday Bash (Noble, 1989). The students did not have prior knowledge of the picture book. The illustration was of Jimmy's birthday party, with crazy party hats, a boa constrictor in the swimming pool, and ice cream everywhere. The child's task was to talk aloud and help the Spelling Bee write a detailed description of the picture for the puppet's friend. The writing activity took approximately 60 minutes.

\section{DATA ANALYSIS}

Analysis of the data was systematic. Measures included constant comparative analysis (Glaser \& Strauss, 1967), the "method of differences," and a synthesis of other procedures (Miles \& Huberman, 1990). Analysis was recursive, moving between developmental spelling stage theory and the data. It was also generative as a categorical scheme developed.

The goal of the analysis was to examine the children's written spellings, as well as descriptions of their spelling knowledge. The authors divided verbal descriptions of spelling knowledge into thought units for each spelling task. They defined a thought unit as an episode of communication during which the student applied, or described spelling knowledge. For example, during the writing activity, Kurt wrote flote for the word float. The puppet asked: "How did you know there was an $E$ on the end?" His response: "remember, the $E$ makes the $O$ or $A$ or $I$ say its name," is an example of a thought unit because Kurt is describing spelling knowledge. Each sentence directly related to the writing process and/or spelling was recorded as a thought unit. Remarks not related to spelling were not counted. Each thought unit underwent coding, categorization, and quantitative analysis.

Different kinds of spelling knowledge emerged with multiple readings of the students' data records. A coding system was developed to refine and categorize the kinds of spelling knowledge described in the thought units. A second rater who was unfamiliar with the study assessed reliability in applying the coding scheme. Interrater agreement of $85 \%$ was achieved and discussion resolved disagreements. Final categorical definitions survived a search for disconfirming evidence.

The recursive-generative process yielded two major categories: (1) written developmental stage spelling knowledge and (2) verbalized spelling knowledge. Descriptive subcategories define the major categories. Each descriptive category has a percentage of thought units calculated rather than a frequency tally. Triangulation of data sources to enhance descriptive power includes quotes from the audiotapes, excerpts from field notes and examples from written documents. Each provides connections among the data, major category distinctions, and the subcategories.

\section{RESULTS}

\section{Written Developmental Stage Spelling Knowledge}

Table 1 shows representative written spellings for each child for the qualitative spelling inventory and the writing activity. Based on their written spellings, Kurt and 
Betty appear to have been in the within-word pattern stage of spelling development, while Mark and Tammy were in the higher, syllable juncture stage. Betty (belowaverage) and Mark (above-average) had Ms. P ("Ms. Phonics") for first grade, while Kurt (below-average) and Tammy (above-average) had Mrs. I ("Ms. Invented Spelling").

Kurt showed earlier stage knowledge as well. For example, he demonstrated sound/symbol knowledge when he omitted the letter $H$ in the word when. He omitted the preconsonantal nasal in the word bump (bup) and spelled the TR blend in the word train with the letters $\mathrm{CH}$. These spelling patterns are found in the late letter-name stage of spelling development.

Betty's written spellings also showed late letter-name stage knowledge. She substituted the letter $E$ for the letter $I$ in the word ship; omitted the letter $L$ in the $F L$ blend in the word float; and left off the long vowel marker at the end of chase by spelling chas. This is also evidence of some confusion with within-word patterns; which is the stage that follows the letter-name stage.

The below-average spellers had mastered initial and final consonants and were aware that each syllable required a vowel. They consistently used the long vowel marker $E$ at the end of the word, and most of their blends and digraphs were correct. During the writing activity Betty and Kurt spelled the word bowl as bole. This placed them in the early within-word pattern stage of spelling development. They both used the blend $D R$ correctly in the word drive along with the vowel marker $E$, and used the digraph $S H$ correctly in the word ship. Both below-average spellers replaced the suffix $E D$ with the letter $T$. Betty spelled the word jumped as jumpt and again Kurt omitted the preconsonantal nasal $M$, when he spelled the word jump as jupt; a pattern that withinword spellers "use but confuse" in their writing.

Mark and Tammy (the above-average spellers) were at the within-word spelling stage of development and showed many characteristics of the early syllable junctures stage. In contrast to Betty and Kurt, they were able to spell the word bowl correctly during the writing activity. They both spelled cellar as seller. Mark doubled the consonant in the word popping. Tammy did not. Neither of them doubled the consonant in the word cattle. Consonant doubling is often "used but confused" in this stage and children spell sounds at syllable junctures like single-syllable words: Tammy spelled the word puncture, punshered and Mark spelled the word pleasure, plesher.

The four students' written spellings appear to conform to stages described in developmental stage theory.

\section{Verbalized Spelling Knowledge}

1. Sound/symbol. Children's verbalized, as opposed to written spelling knowledge in this subcategory focused attention on the sound/symbol relationship(s) in a word. Kurt's description of how to spell bed is an example:

Kurt: Bed

Bee: What does it start with?

Kurt: $B$

Bee: Why does it start with a $B$ ?

Kurt: Bed starts with a buh.

Bee: What comes next? 
Kurt: eh

Bee: How do you know that?

Kurt: $E h, B-E-D$. Do you hear that?

Kurt: $B e d, D$, says $d u h$.

This category also includes knowledge of sounds of single consonants and blends in beginning and final positions. Consider Betty's acquisition of the beginning blend $S-Q-U$ :

Bee: Spell squirrel

Betty: $S-Q-U$

Bee: How did you know that?

Betty: I know $S-Q-U$. We had it on a test.

Bee: You can't have a $Q$ without what?

Betty: A $U$

Bee: What's next?

Betty: $R$ says er

Bee: How do you know what letter to put with $\mathrm{R}$

Betty: $R$ sounds different

Betty: Then an $L$

2. Conscious Nonuse of Sound/symbol. Another way the students used sound/symbol knowledge was by explaining to the Bee how they "used to" spell words. During the writing activity Betty wrote the word are:

Betty: $A-R-E$

Betty: When I was in kindergarten I used to put the letter $R$ for are.

3. Within-word Letter Patterns. An example of verbalized spelling knowledge in this sub-category focuses on letter patterns that mark a vowel (cape vs. cap, or flote vs. float). Tammy explained the vowel marker in the word time: "In the word time the $E$ makes the $I$ say its name and the $M$ separates them."

Tammy further illustrated her within-word pattern knowledge:

Bee: $\quad$ Spell beaches.

Tammy: $B$ makes the sound like you, Bee.

Tammy: $E$ says eeee, but all by itself it says $e h$, so I'm putting $E-A$.

Bee: $\quad$ What's the $A$ do?

Tammy: When two vowels go walking, the first one does the talking.

Kurt demonstrated early letter-name knowledge $(\mathrm{C}-\mathrm{H}$ representing the initial phonemes in train) as well as familiarity, though not accuracy, with long-vowel markers which is also representative of the within-word letter pattern stage: 
Bee: Spell train

Kurt: $C-H$

Bee: So $C$ - $H$ says $t r$ ?

Kurt: Yes

Kurt: $R-A-N$

Kurt: $\mathrm{E}$ at the end

Bee: How do you know that?

Kurt: $E$ makes the $A$ says its name, ay

Bee: Spell float

Kurt: $F a$, no $f u l$

Kurt: $O$, cause it's O flote

Kurt: $T$

Kurt: $E$, remember cause $E$ makes $O$ or $A$ or $I$ say its name

4. Across-word Meaning Patterns. Verbalized spelling knowledge in this subcategory focused attention on the relationship between a word's meaning and its spelling. This knowledge was emergent and tentative and did not necessarily result in a correct spelling:

Tammy: T-H-E-R-E, there. It's not like their house.

Bee: How would you spell that kind of their?

Tammy: T-H-I-R-E

Betty: T-H-I-E-R. No, its not the kind of their I want.

Bee: What kind do you want?

Betty: Their birthday, T-H-E-R-E

5. Syllable Juncture Patterns. This subcategory focused on syllable juncture patterns such as $s$, ed, and most common inflections (e.g., jumped vs. jumpt); consonant doubling (popping vs. poping); and e-drop (having vs. haveing). While spelling the word beaches, the bee asked Mark how he knew there was an ES at the end of the word. He replied, "because if it ends in $S, H$, and $X$ you put $E S$ to make it plural." Tammy knew how to drop the $E$ before adding ing in the word having during the writing activity, however her rationale was confusing.

Tammy: They're having, $h a, h a, h a, v a, v a$, ing. You drop the $E$ because you can't do two vowels go walking the first one does the talking 'cause they both need to make the sound.

The following example shows that Tammy's pattern knowledge was not yet focused on syllables:

Bee: Spell chase

Tammy: $C-H$ says $c h a$

Tammy: You can kind of hear the $C$ and you kind of hear the $H$ 
Bee: Do you hear them separately or together?

Tammy: Together

Tammy: Then, $A-S-E$

Tammy: The $E$ at the end makes the $A$ say its name

Tammy: Remember spelling bee, there always has to be a vowel in one word

Bee: Does each syllable need a vowel?

Tammy: No

6. Letter Formation. Spelling knowledge in this subcategory was mediated by letter formation. Although Mark spelled nearly all words with automaticity, he stopped to think about letter formation in the following example:

Mark: I'm going to spell the word drive. It starts with a $D$.

Mark pauses.

Bee: Are you trying to figure out which direction the $D$ goes?

Mark: Yes

7. Visual Strategies. Spelling knowledge categorized as use of a visual strategy surfaced relative to words the students stated that they could spell because they had previously spelled them on a spelling test, or written them in a story at school. Betty spelled the word bump confidently during the spelling inventory. When the Bee asked how she knew it she answered, "cause I wrote it in my elf story at school." During the writing activity Betty wrote gold:

Bee: How did you know?

Betty: I know because I wrote it in a story

Bee: Are those easy for you once you have written them in a story?

Betty: Yes

Kurt provides two more illustrations of use of a visual strategy:

Kurt: At the party we all...

Bee: How did you know how to spell the word all?

Kurt: Because we had it on a spelling test.

Bee: How did you know pool had 2 Os?

Kurt: It was on our spelling test

8. Automaticity. This type of spelling knowledge resulted in rapid and unmediated access to a word's spelling. Unmediated means there are no strategies in use other than "I just know it." In this study it was not necessary that the resultant written spelling be orthographically accurate. After spelling the word bed, the bee asked Mark why he spelled it that way, and Mark replied, "because I have to." The following is another illustration of Mark's automaticity, this time intersecting with his syllable juncture knowledge: 
Mark: Swimming, $S-W-I-M-M-I-N-G$

Bee: Do you hear two $M$ 's.

Mark: No you just double it 'cause swim is $S-W-I-M$ and swimming is

$S-W-I-M-M-I-N-G$.

Kurt spells popping with automaticity, although the resultant spelling is not a conventional spelling:

Bee: Spell popping

Kurt: Poping, pa, ah, pa, pop

Kurt: I-N-G spells ing

Bee: How did you know that?

Kurt: I definitely know how to spell that because I like popcorn.

Tammy provided an example of automaticity beyond within-word pattern knowledge. She provided pattern knowledge to show the Bee how to spell train, but she made it clear that she "knows the word:"

Bee: Spell train

Tammy: Ter, ter, $T-R$ makes that sound

Tammy: $A$-I makes ay

Tammy: It's kind of weird, because it could be $A-N-E$ or $A-I$

Bee: How did you decide to pick $A-I$ ?

Tammy: I know the word. $A-I$ this time.

Tammy: $N$ for $n n n$

All four students used automaticity while writing the high frequency words such as, the, my, it, like, etc. during the writing activity.

9. Risk Taking. A positive risk-taking attitude toward spelling (i.e., "I'll try!") mediated all students' verbalized spelling knowledge in this subcategory. Whether to use the letter $C$ or the letter $K$ posed a challenge for the students and they became risk-takers. For example:

Bee: Spell caught.

Kurt: I think it's a $C$ this time

Bee: Why do you think it's $C$ this time?

Kurt: I don't know, it just sounds right. It sounds original.

Bee: Sounds original. Well last time you thought it was a $K$.

Bee: Do you know when it's a $C$ or a $K$, or do you just guess?

Kurt: I kind of just guess, kind of know.

In the next example, Kurt was also unsure about whether or not to double the consonant in cattle. Although he is choose to double the $\mathrm{L}$ for reasons unrelated to syllable juncture 
patterns (the word all was on Kurt's spelling test), he demonstrated a positive risk-taking attitude.

Bee: Spell cattle

Kurt: That's hard

Bee: Just try

Kurt: $C$ or a $K$

Bee: Which one?

Kurt: $K$

Kurt: a, $a$, at

Kurt: $L-L$, I am going with two $L$ s

Bee Why?

Kurt: It says all

Bee: You happy with that?

Kurt: Yeah.

When spelling the word cattle during the spelling inventory, Tammy had her own way to differentiate between a $C$ and a $K$ :

Tammy: $K i, K i$.

Bee: $\quad$ How do you know if it starts with a $C$ or a $K$ ?

Tammy: Cause a $C$ sounds different from a $K$, kind of.

Tammy: $C$ goes $k i, k i, k i$. A $K$ goes $k a, k a, k a$.

Bee: I can't hear the difference.

Tammy: I can't really tell you.

Bee: $\quad$ But you think a $C$ and $K$ sound different?

Tammy: Yeah

10. Other spelling knowledge. Thought units coded as "other" reflected verbalized spelling knowledge that was (a) not suggested by a child's written spellings, (b) not described clearly by the child, and/or (c) specific to an individual student. This subcategory was dropped from further analysis.

\section{Patterns of Verbalized Spelling Knowledge}

Table 2 displays the subcategories of verbalized spelling knowledge that each of the four students exhibited. The numbers represent percentages of thought units by subcategory and spelling task. As defined earlier, thought units are episodes of communication during which the students applied one or more subcategories of spelling knowledge. The table shows that all four children had some degree of spelling knowledge in each of the ten subcategories. This information is not entirely available from traditional or developmental assessments of spelling that are based on written spellings.

However, there were differences in the degree to which the children used or talked about specific subcategories of spelling knowledge during the two spelling tasks. Table 3 differentiates the below-average and the above-average spellers' spelling knowledge in each of the ten subcategories for both the qualitative spelling inventory and 
the writing activity. Again, the numbers represent percentages of thought units by subcategory and spelling task. The patterns that emerge in Table 3 suggest relationships among the children's spelling knowledge, achievement, and the spelling task. For example, although below-average spellers used sound/symbol knowledge, they relied primarily on within-word pattern knowledge during the spelling inventory and the writing activity. The above-average spellers still used sound/symbol and within-word knowledge, but relied primarily on syllable juncture knowledge during both tasks. Both belowaverage and above-average spellers described sound/symbol knowledge only during the writing activity.

Although the below-average spellers described some syllable juncture knowledge during the writing activity, they also found it confusing. Both the above-average and below-average spellers showed evidence of across-word meaning knowledge, but only during the writing activity.

Both groups of spellers were conscious of their letter formation knowledge, however only during the spelling inventory. All four students had some confusion when writing the letters $B$ and $D$. Betty and Mark verbalized their confusion before writing the letter; whereas Kurt and Tammy simply reversed the letters without noticing they were incorrect. The below-average spellers used visual strategies on both tasks; however the above-average spellers used the visual strategies only during the spelling inventory. All four spellers revealed the use of automaticity, however the below-average spellers used considerably less (2\% during the spelling inventory and 5\% during the writing activity) than the above-average spellers (25\% during the spelling inventory, and $25 \%$ during the writing activity). All four students demonstrated risk-taking, but it was the below-average spellers who took these positive ("I'll try!") risks more often.

Other patterns that emerged from the data suggest a tentative relationship between certain aspects of the children's spelling knowledge and their first grade teachers' approach to spelling instruction. Table 4 differentiates the two groups of spellers' spelling knowledge in each of the ten subcategories for both the spelling inventory and the writing activity. As stated previously, Ms. P ("Ms. Phonics") (with Mark, aboveaverage speller and Betty, below-average speller) discouraged the use of invented spelling, and Mrs. I ("Ms. Invented Spelling") (with Tammy, above-average speller and Kurt, below-average speller) encouraged the use of invented spelling.

Ms. P's students demonstrated more use of within-word knowledge during the writing activity than Mrs. I's students but less during the spelling inventory. Ms. P's students also demonstrated more syllable juncture knowledge during both tasks than did Mrs. I's students. Ms. P's students, who were discouraged from using invented spelling in first grade, displayed more automaticity than Mrs. I's class during the spelling inventory and the writing activity. Ms. P's students displayed more risk-taking during the writing activity and the same amount as Mrs. I's students during the spelling task. However, Table 1 reveals that Kurt (the below-average speller from Mrs. I's class) displayed nearly three times more risk-taking than the other three students.

\section{DISCUSSION}

This study describes and categorizes the spelling knowledge of four-second graders, two below- and two above-average spellers. One below- and one above-average speller came from a first grade classroom where invented spelling was encouraged. The 
other below- and above-average spellers came from a first grade classroom where invented spelling was not discouraged. The results, which should be interpreted heuristically and relative to the qualitative research method with which the data were obtained, suggest a relationship among the participants' patterns of spelling knowledge, their spelling achievement, and the spelling task. Only tentative relationships are suggested between the participants' spelling knowledge and their first grade spelling instruction.

Stage Theory

Developmental stage theory provides an obvious explanation for the relationship between spelling ability and the patterning of spelling knowledge in the following subcategories: written spellings, sound/symbol, conscious nonuse of sound/symbol, within-word letter patterns, across-word meaning patterns, and syllable juncture patterns. Hierarchically, sound/symbol knowledge precedes within-word letter pattern knowledge, which precedes across-word meaning pattern knowledge, followed by syllable juncture pattern knowledge (Ehri, 1997; Gentry, 1982; Henderson, 1990; Read, 1986). In this study the below-average spellers were primarily in the within-word pattern stages of spelling development. The above-average spellers were primarily in the syllable juncture pattern stage of spelling development. However, the invented spellings of the four participants show spelling pattern characteristics found in more than one developmental stage. For example, Kurt's spelling knowledge showed signs of sound/symbol pattern knowledge, letter-name pattern knowledge and within-word pattern knowledge.

The transitions between stages are gradual and the boundaries between stages of development can be indistinct (Bear et al., 2000). All four participants were approximately the same age. This study's results confirm that age is merely a guidepost as to when developmental accomplishments can be expected and that a range of spelling abilities may be displayed at any given age.

Only the below-average spellers, Betty and Kurt, wrote words that were classified as being in the letter-name stage of spelling development. One of the primary characteristics of a child at Piaget's preoperational level is centering on the single most dominant characteristic of an object. The below-average spellers' inconsistent ability to perceive other significant features may have been reflected in their more frequent use of the letter-name strategy. For Kurt and Betty, the names of the letters became the single most dominant feature used to spell these words. The above-average spellers, Mark and Tammy, did not use the letter-name strategy frequently or consistently. They were probably, according to Piaget, at a higher cognitive learning stage than Betty and Kurt. This lends support to the theory that there is a relationship between cognitive development and spelling development.

Children may perceive phonetic properties unnoticed by their parents and teachers. Read's (1971) early study of invented spellings revealed that it is not uncommon for children to use the letters $C H R$ to represent the sound $t r$ at the beginning of a syllable. The errors have a reasonable phonetic basis because when $T$ occurs before $R$, the place of articulation moves in the mouth and the closure is released slowly rather than quickly, giving $T$ a degree of frication. The pronunciation is similar to the initial sound of the word chick. Making a similar error earlier in the school year, Kurt 
repeatedly substituted the letter $J$ for $D$, as in jragon for dragon. Spellings such as $C H$ or $J$ for $T$ generally occur when $T$ or D are followed by $R$; they are less common when these letters occur in other contexts.

There is also theoretical support for this study's findings relative to the patterning of verbalized spelling knowledge not explained by stage theory in the following subcategories: letter formation, visual strategies, automaticity and risk-taking. Hoffman and Norris (1989) proposed that children's spelling reflects the complexity of the connections between experiences with auditory and visual modes of representing language. They suggest that because the auditory system is the primary mode of learning language for most children, the auditory-speech-motor connections are greater than those for visual representation. Thus, when young children begin to write, these auditoryspeech-motor connections contribute more to their spellings. They posit that a child with less experience with print will rely primarily on the sound/symbol system because of a failure to acquire the complex connections for the conventions of visual representation. A child with a great deal of print exposure can more easily incorporate conventions of the visual representations of words. Hoffman and Norris suggest that this is why children whose spelling is orthographically correct for words in their reading or spelling vocabulary revert to phonetic representations for words that are not. This was represented in all four participants' spelling knowledge and may explain the occasional motor hesitations relative to the formation of the letters $B$ and $D$.

However, more recently Lennox and Siegel (1998) found that above-average spellers successfully use both visual and phonological cues to a greater extent than do age-matched below-average spellers. They suggest that phonological skills are deficient in below-average readers and spellers, but that certain visual memory skills are equivalent or better than in the average population. Thus, when below-average spellers approach difficult words, they must rely on visual memory skills, whereas above-average spellers can access well-developed phonological skills. This theory provides a possible link to Kurt and Betty's increased use of visual strategies during the writing activity and their lower stage of spelling development on both spelling tasks than either Mark's or Tammy's.

There is another possible explanation for the below-average spellers' more frequent use of visual strategies. Not all children bring common experiences to the spelling task. Children's senses and motor mechanisms contribute to their concept development in divergent ways, and individuals differ in their learning rate and style. These differences influence the acquisition of spelling ability. Hanna, Hodges, and Hanna (1971), suggest that some students are predominantly "visual-minded" and store a visual image of a word in their lexicon. Others are "hand-minded" and are likely to rely upon writing a word to be sure that it is spelled correctly. In this study, it may be that the below-average spellers had less experiences with writing than the above-average spellers and, hence, relied upon visual strategies rather than writing strategies.

Additionally, there are three distinct ways to spell words: by memory, by invention, and by analogy (Ehri, 1992). Which process is used depends on whether the written forms of the words are familiar or unfamiliar. Familiar words are spelled by accessing representation in memory. Unfamiliar words are spelled by invention or by analogy and children draw on phonological and visual strategies from the very beginning. This might explain why the below-average and above-average spellers reverted back and 
forth between sound/symbol spelling pattern knowledge and visual spelling pattern knowledge throughout both spelling tasks.

The above-average spellers, who were also above-average readers (see Table 3), were more likely to be automatic spellers. An unmediated, lexical access to a word's spelling is more rapid (i.e., automatic) than one mediated by auditory-speech-motor connections. It is also dependent on a considerable personal store of words in the lexicon and opportunities to practice their retrieval. The two above-average spellers may simply have had more words in their reading and spelling vocabularies and more opportunities to use them. Because automaticity results from over learning, the above-average spellers' repeated practice potentially freed their attention such that they did not have to focus on the mechanics of encoding during the spelling tasks. However, for some children, extensive reading might not be an effective means of building a lexicon. This is because an above-average reader, who attends only to partial cues during reading, may not transfer much useful information to the spelling process (Frith, 1980).

Although there were few notable differences in the written and verbal spelling knowledge of the spellers from Ms. P and Ms. I's first grade classes, Kurt, the belowaverage speller from the invented-spelling first-grade classroom, made considerably more risk-taking attempts during the writing activity than did any of the other three spellers. Similar differences, relative to risk-taking surfaced in the spellers' second grade classroom. Tammy and Kurt (from Ms. I's first-grade class in which invented spelling was encouraged) were comfortable and at ease while writing and their pieces were more creative and longer in length (Clarke, 1988) than either Mark's or Betty's.

By the end of first grade, children who are encouraged to use invented spellings typically score as well or better on standardized tests of spelling than children who are allowed to use only correct spellings during writing activities (Clarke, 1988). In second grade, the two below-average speller's scores (Betty and Kurt), and the two aboveaverage speller's scores (Tammy and Mark), on the state standardized spelling test were within $5 \%$ of one another on the number of questions answered correctly.

Invented spelling is just one of the many factors that can affect a child's phonological and orthographic knowledge. In this study, although both first-grade teachers differed in their approach to teaching phonological awareness, they each taught it using a commercial program and for a similar block of time during the school day. This may explain the similarities in the four students' spelling knowledge across many of the subcategories. In addition, there are many differences in the way individual children process and learn. Therefore, the results of this study might be different if the instructional methods used to teach literacy in the participants' classrooms, had coincided differently with the way each processes and learns information.

There are other limitations of this study's results. First, this study occurred in April of the students' second-grade year and any effects of their first-grade teachers' instructional methods might be masked by the second author's instructional practices during their second-grade year. Second, the extent to which other variables in the students' learning environment(s) influenced the results is not known. For example, how and when does students' spelling knowledge become their own and not simply a reflection of the knowledge that they are taught? Third, because the focus was on only one stage of the students' development (i.e., their second grade year), further 
investigations of students' spelling knowledge at various stages of development are warranted.

Implications for Instruction

Implications for instruction focus on two related subcategories: risk taking and automaticity. It is interesting to note that both risk-taking and automaticity support students' writing in similar ways. Both processes enable writers to communicate fluently and authentically at the discourse level with relatively little attention devoted to conventional encoding at the word level.

First, it is important for students to take cognitive risks and invent spellings for words as they write. Whether or not a resultant spelling is conventional, two things happen. One, students remain engaged in the writing process and are able to select meaningful words whether or not they are able to spell them and two, by inventing a spelling, students access the alphabetic principle. It is important for teachers to encourage and assess their students' invented spellings for developmental change. However, it is also important to develop students' spelling automaticity and provide them with multiple opportunities to obtain a lexical access to a word's conventional spelling. This type of access is faster than one mediated solely by letter-sound connections, but is dependent on a substantial store of words in the lexicon. Teachers can incorporate instructional activities that support risk-taking and automaticity, as well as the students' developmental stage(s). For example, for students who invent spellings which may indicate they are in the letter name stage of development, Writing with Word Boxes is a useful activity which is adapted from Elkonin (Sipe, 2001) who developed word boxes to help children attend to phonemes. The technique involves providing children with a double page for writing activities. The bottom portion is the story writing section and the top portion is used for spelling study. Students write their story on the bottom half. Words that require an invented spelling are explored on the top half using a word box. Teachers make a word box by drawing a box for the word that is a rectangle with partitions that correspond to the sounds in the invented spelled word. Using markers, (pennies work well), teachers can help the student articulate each sound in the word while pushing a marker into the appropriate compartment. Next, teachers ask the student to move the markers up, articulate the sound for each compartment in the box and write the letter(s) that represent the sound that is heard in the appropriate compartment. Finally, teachers have the student transfer the word in the box into the story. If the word is a multisyllable word, teachers show the student how to clap the syllables. This helps to segment the parts of the word so that it can be more easily written. For a focus on automaticity, teachers make boxes with compartments that correspond to the number of letters (rather than sounds) in the word. This way, students will attend to how the word looks as well as how it sounds. The drafting stage of writing is an ideal time for students to independently create and communicate with an emphasis on the process of spelling. Helping students develop automaticity shifts the emphasis to product and coincides with the editing and publishing stages of the wrting process. It may well be that process and product cannot be separated.

Further investigation of the ways in which children spell words and the contexts in which they spell them is needed in order to extend the applicability of theories about spelling knowledge. Researchers might continue to explore 
- The developmental aspects of learning to spell

- The difference between children's developmental spelling knowledge and their learned spelling knowledge

- What teachers actively do to assist students' spelling development and/or spelling knowledge 
Table 1.

Representative Written Spellings

\section{Qualitative Spelling Inventory}

\begin{tabular}{lllll}
\hline Correct Spelling & Kurt & Betty & Mark & Tammy \\
\hline 1. bed & bed & bed & bed & bed \\
2. ship & ship & shep & ship & ship \\
3. drive & drive & drive & drive & drive \\
4. bump & bup & bump & bump & bump \\
5. when & wen & when & when & when \\
6. train & chrane & train & train & train \\
7. closet & clozit & coluist & closet & closet \\
8. chase & chase & chas & chase & chase \\
9. float & flote & foat & float & flote \\
10. beaches & dechez & bechis & beaches & beaches \\
11. preparing & prepareening & pareaing & preparing & prepairing \\
12. popping & poping & poping & popping & poping \\
13. cattle & katll & katll & catle & catle \\
14. caught & cot & cat & coght & caut \\
15. inspection & inspecshen & inspshin & insectchon & inspetoin \\
16. puncture & puncsher & pusher & poncter & punshered \\
17. cellar & seller & seler & seller & seller \\
18. pleasure & plere & plegher & plesher & pleser \\
19. squirrel & sweril & squrl & squrill & squirle \\
20. fortunate & forchenit & foruinit & forchinet & forchenit \\
\hline
\end{tabular}

Writing Activity

\begin{tabular}{lllll}
\hline Correct Spelling & Kurt & Betty & Mark & Tammy \\
\hline 1. party & pertee & party & party & party \\
2. boa constrictor & douinscrinter & boa kusher & boa castriter & boa constricktor \\
3. ice-cream & ick ceem & ice cerm & ice cream & ice-cream \\
4. cake & kace & cake & cake & cake \\
5. octopus & octpis & oapus & octapuses & oktapoos \\
6. gold & gold & gold & gold & gold \\
7. fishes & fishes & fesh & fishes & fishes \\
8. jumped & jupt & jumpt & jumped & jumped \\
9. pool & pool & pool & pool & pool \\
10. balloons & dloos & balloon & ballon & balloon \\
11. boys & duys & boys & doys & boys \\
12. girls & grlla & grils & girls & girls \\
13. snake & snac & snak & snake & snake \\
14. hats & hats & hats & hats & hats \\
15. bowl & bole & bole & bowl & bowl \\
16. swimming & swimming & siwmming & swmming & swimming \\
\hline
\end{tabular}


Table 2.

Patterns of Spelling Knowledge

\begin{tabular}{lrrrr}
\hline \multicolumn{1}{c}{ Subcategory } & Kurt & Betty & Mark & Tammy \\
\hline Writing activity & 15 & 20 & 0 & 14 \\
Sound/symbol & 7 & 6 & 9 & 0 \\
Sound/symbol (conscious nonuse) & 42 & 49 & 17 & 17 \\
Within-word pattern & 2 & 2 & 1 & 7 \\
Across-word meaning pattern & 2 & 4 & 33 & 35 \\
Syllable-juncture & 0 & 0 & 0 & 0 \\
Letter formation & 7 & 10 & 0 & 0 \\
Visual strategies & 7 & 4 & 32 & 18 \\
Automaticity & 16 & 5 & 7 & 6 \\
Risk taking & 2 & 0 & 1 & 3 \\
Other & & & & \\
Spelling Inventory & 25 & 22 & 2 & 13 \\
Sound/symbol & 0 & 0 & 0 & 0 \\
Sound/symbol (conscious nonuse) & 57 & 52 & 18 & 22 \\
Within-word pattern & 0 & 0 & 0 & 0 \\
Across-word meaning pattern & 3 & 4 & 40 & 32 \\
Syllable-juncture & 2 & 2 & 3 & 2 \\
Letter formation & 1 & 4 & 6 & 3 \\
Visual strategies & 2 & 3 & 26 & 24 \\
Automaticity & 10 & 10 & 3 & 4 \\
Risk taking & 0 & 3 & 2 & 0 \\
Other & & & &
\end{tabular}

Note.-Values represent percentages of thought units. 
Table 3.

Below-Average and Above-Average Spellers' Patterns of Spelling Knowledge

\begin{tabular}{lrrrr} 
& \multicolumn{2}{c}{ Writing Activity } & \multicolumn{2}{c}{ Spelling Inventory } \\
\hline Subcategory & $\begin{array}{c}\text { Below- } \\
\text { Average } \\
\text { (Kurt \& } \\
\text { Betty) }\end{array}$ & $\begin{array}{c}\text { Above- } \\
\text { Average } \\
\text { (Mark \& } \\
\text { Tammy) }\end{array}$ & $\begin{array}{r}\text { Below- } \\
\text { Average } \\
\text { (Kurt \& } \\
\text { Betty) }\end{array}$ & $\begin{array}{r}\text { Above- } \\
\text { Average } \\
\text { (Mark \& } \\
\text { Tammy) }\end{array}$ \\
\hline Sound/symbol & 8 & 7 & 23 & 7 \\
Sound/symbol (conscious nonuse) & 17 & 4 & 0 & 0 \\
Within-word pattern & 45 & 17 & 55 & 20 \\
Across-word meaning pattern & 2 & 4 & 0 & 0 \\
Syllable-juncture & 3 & 34 & 4 & 36 \\
Letter formation & 0 & 0 & 2 & 3 \\
Visual strategies & 9 & 0 & 3 & 4 \\
Automaticity & 5 & 25 & 2 & 25 \\
Risk taking & 10 & 7 & 10 & 4 \\
Other & 1 & 2 & 1 & 1 \\
\hline Note.- Valus & & & & \\
\end{tabular}

Note.- Values represent percentage of thought units. 
Table 4.

Ms. C's ( - Invented Spelling) and Ms. N's ( + Invented Spelling) Students'

Patterns of Spelling Knowledge

\begin{tabular}{lllll} 
& \multicolumn{2}{c}{ Writing Activity } & \multicolumn{2}{c}{ Spelling Test } \\
\hline \multicolumn{1}{c}{ Subcategory } & Ms. C's & Ms. N's & Ms. C's & Ms. N's \\
& Students & Students & Students & Students \\
& (Betty \& & (Kurt \& & (Betty \& & (Kurt \& \\
& Mark) & Tammy) & Mark) & Tammy) \\
\hline Sound/symbol & 10 & 15 & 12 & 19 \\
Sound/symbol (conscious nonuse) & 7 & 4 & 0 & 0 \\
Within-word pattern & 33 & 30 & 35 & 40 \\
Across-word meaning pattern & 3 & 4 & 0 & 0 \\
Syllable-juncture & 18 & 18 & 22 & 17 \\
Letter formation & 0 & 0 & 2 & 2 \\
Visual & 5 & 4 & 5 & 2 \\
Automaticity & 18 & 12 & 15 & 13 \\
Risk taking & 6 & 10 & 7 & 7 \\
Other & 0 & 3 & 2 & 0 \\
\hline
\end{tabular}

Note.- Values represent percentage of thought units. 


\section{REFERENCES}

Bear, D., Invernizzi, M., Johnston, F. \& Templeton, S. (2000). Words their way: Word study for phonics, vocabulary, and spelling instruction ( $2^{\text {nd }}$ ed.). Upper Saddle River,NJ: Prentice-Hall Inc.

Clarke, L. K. (1988). Invented versus traditional spelling in first graders' writings: Effects on learning to read and spell. Research in Teaching of English, 22, 281309.

Cunningham, P. (2005). Phonics they use: Words for reading and writing (3rd ed.). Boston: Allyn \& Bacon.

Dahl, K., Barto, A., Bonfils, A., Carasello, A., Christopher, J., Davis, R. et al. (2003). Connecting developmental word study with classroom writing: Children's descriptions of spelling strategies. The Reading Teacher, 57(4), 310-319.

Ehri, L.C. (1992). Review and commentary: Stages of spelling development. In S. Templeton \& D. Bear (Eds.), Development of orthographic knowledge and the foundations of literacy: A memorial festschrift for Edmund Henderson (pp.307332). Hillsdale, N.J.: Lawrence Erlbaum.

Ehri, L.C. (1997). Learning to read and learning to spell are one and the same, almost. In C. A. Perfetti, L. Rieben, \& M. Fayol (Eds.), Learning to spell: Research theory, and practice across languages (pp.237-269). Mahwah, N.J: Lawrence Erlbaum.

Ericsson, K.A. \& Simon, H.A. (1980). Verbal reports as data. Psychological Review, 87, 215-251.

Frith, U. (1980). Cognitive process in spelling. London: Academic Press.

Gentry, J.R. (1982). An analysis of developmental spelling in GNYS at work. Reading Teacher, 36,192-200.

Gentry, J.R. (2000). A retrospective on invented spelling and a look forward. The Reading Teacher, 54, 318-332.

Glaser, B.G. \& Strauss, A.L. (1967). The discovery of grounded theory: Strategies for qualitative research. Chicago:Aldine Publishing Company.

Hanna, P., Hodges, R. \& Hanna, J. (1971). Spelling structure and strategies. Boston: Houghton Mifflin.

Henderson, E.H. (1981). Learning to read and spell: A children's knowledge of words. DeKalb, IL: Northern Illinois University Press.

Henderson, E. (1990). Teaching spelling ( $2^{\text {nd }}$ ed.). Boston: Houghton Mifflin. 
Heydon, R., Hibbert, K. \& Iannacci, L. (2004-2005). Strategies to support balanced literacy approaches in pre- and inservice teacher education. Journal of Adolescent \& Adult Literacy, 48(4), 312-319.

Hoffman, P.R. \& Norris, J.A. (1989). On the nature of phonological development: Evidence from normal children's spelling errors. Journal of Speech and Hearing, 21, 787-794.

Kress, G. (2000). Early spelling: Between convention and creativity. New York: Routledge.

Lennox, C. \& Siegel, L. (1998). Phonological and orthographic processes in good and poor spellers. In C. Hulme \& R. Malatesha Joshi (Eds.), Reading and spelling: Development and disorders (pp.397-404). New York: Academic Press.

Miles, M .B. \& Huberman, A. M. (1990). Qualitative data analysis: A sourcebook of new methods. Newberry Park, CA: Sage.

Noble, T. H. (1989). Jimmy's boa and the big splash birthday bash. New York: Dial Book for Young Readers.

Read, C. (1971). Pre-school children's categorizations of speech sounds in English phonology. Harvard Educational Review, 41, 1-34.

Read, C. (1975). Children's categorization of speech sounds in English. Urbana, Illinois: National Council of Teachers in English.

Read, C. (1986). Children's creative spelling. London: Routledge \& Kegan Paul.

Schlagal, B. (2001). Traditional, developmental, and structured language approaches to spelling: Review and recommendations. Annals of Dyslexia, 51, 147-176.

Sipe, L. R. (2001). Invention, convention and intervention: Invented spelling and the teacher's role. The Reading Teacher, 55, 264-274.

Weiner, S. (1994). Four first grader's descriptions of how they spell. The Elementary School Journal, 94(3), 315-330.

Wilde, S. (1986). An analysis of the development of spelling and punctuation in selected third and fourth grade children. (Report No. CS 210-727). Tucson: University of Arizona, College of Education. 
APPENDIX A

Spelling Stages Suggested By Qualitative Spelling Inventory

\begin{tabular}{|c|c|c|c|c|c|}
\hline Stages & $\begin{array}{l}\text { Early } \\
\text { Letter } \\
\text { Name }\end{array}$ & $\begin{array}{l}\text { Letter } \\
\text { Name }\end{array}$ & $\begin{array}{l}\text { Within } \\
\text { Word } \\
\text { Pattern }\end{array}$ & $\begin{array}{l}\text { Syllable- } \\
\text { juncture }\end{array}$ & $\begin{array}{l}\text { Derivational } \\
\text { Constancy }\end{array}$ \\
\hline 1. bed & $\mathrm{b}$ bd & bad & $\begin{array}{l}\text { bed } \\
\text { Betty, Kurt, } \\
\text { Mark, } \\
\text { Tammy }\end{array}$ & & \\
\hline 2. ship & s sp shp & $\begin{array}{r}\text { sep shep } \\
\text { Betty }\end{array}$ & $\begin{array}{l}\text { Sip ship } \\
\text { Kurt, Mark, } \\
\text { Tammy }\end{array}$ & & \\
\hline 3. drive & jrv drv & griv driv & $\begin{array}{l}\text { drieve draive } \\
\text { drive } \\
\text { Betty, Kurt, } \\
\text { Mark, } \\
\text { Tammy }\end{array}$ & & \\
\hline 4. bump & $\begin{array}{l}\text { b bp } \\
\text { bmp }\end{array}$ & $\begin{array}{l}\text { bop bomp } \\
\text { bup } \\
\text { Kurt }\end{array}$ & $\begin{array}{l}\text { bump } \\
\text { Betty, Mark, } \\
\text { Tammy }\end{array}$ & & \\
\hline 5. when & w yn wn & wan whan & $\begin{array}{c}\text { wen when } \\
\text { Betty, Kurt, } \\
\text { Mark, } \\
\text { Tammy }\end{array}$ & & \\
\hline 6. train & $y \mathrm{t}$ tru & $\begin{array}{c}\text { jran chran } \\
\text { tan tran } \\
\text { Kurt }\end{array}$ & $\begin{array}{l}\text { tran traen } \\
\text { trane train } \\
\text { Betty, Mark, } \\
\text { Tammy }\end{array}$ & & \\
\hline 7. closet & $\begin{array}{l}\mathrm{k} \mathrm{cs} \mathrm{kt} \\
\text { clst }\end{array}$ & $\begin{array}{l}\text { clast clost } \\
\text { clozt }\end{array}$ & $\begin{array}{c}\text { clozit closit } \\
\text { Betty, Kurt, } \\
\text { Mark, } \\
\text { Tammy }\end{array}$ & & \\
\hline 8. chase & j jass cs & $\begin{array}{l}\text { tas cas chas } \\
\text { chase } \\
\text { Betty }\end{array}$ & $\begin{array}{c}\text { case chais } \\
\text { chase } \\
\text { Kurt, Mark, } \\
\text { Tammy }\end{array}$ & & \\
\hline 9. float & $\mathrm{f} v \mathrm{ft} \mathrm{flt}$ & $\begin{array}{c}\text { fot flot flott } \\
\text { Betty }\end{array}$ & $\begin{array}{l}\text { flowt floaut } \\
\text { flote float } \\
\text { Kurt, Mark, } \\
\text { Tammy }\end{array}$ & & \\
\hline $\begin{array}{l}10 . \\
\text { beaches }\end{array}$ & b bs bcs & $\begin{array}{l}\text { bechs becis } \\
\text { behis } \\
\text { Kurt }\end{array}$ & $\begin{array}{l}\text { bechise } \\
\text { beches } \\
\text { beeches } \\
\text { beaches } \\
\text { Betty, Mark, } \\
\text { Tammy }\end{array}$ & & \\
\hline
\end{tabular}




\begin{tabular}{|c|c|c|c|c|c|}
\hline Stages & $\begin{array}{l}\text { Early } \\
\text { Letter } \\
\text { Name }\end{array}$ & $\begin{array}{l}\text { Letter } \\
\text { Name }\end{array}$ & $\begin{array}{l}\text { Within Word } \\
\text { Pattern }\end{array}$ & Syllable-juncture & $\begin{array}{c}\text { Derivational } \\
\text { Constancy }\end{array}$ \\
\hline 11. preparing & & & $\begin{array}{l}\text { Preparing } \\
\text { preypering } \\
\text { Betty, Kurt }\end{array}$ & $\begin{array}{l}\text { preparing } \\
\text { prepairing } \\
\text { preparing } \\
\text { Mark, Tammy }\end{array}$ & \\
\hline 12. popping & & & $\begin{array}{l}\text { popin poping } \\
\text { Betty, } \\
\text { Kurt,Tammy }\end{array}$ & $\begin{array}{c}\text { Pcpping } \\
\text { Mark }\end{array}$ & \\
\hline 13. cattle & & & $\begin{array}{l}\text { catl cadol } \\
\text { Betty, Kurt }\end{array}$ & $\begin{array}{l}\text { catel catle cattel } \\
\text { cattle } \\
\text { Mark, Tammy }\end{array}$ & \\
\hline 14. caught & & & $\begin{array}{c}\text { cot cote cout } \\
\text { cought caught } \\
\text { Betty, Kurt, } \\
\text { Mark, } \\
\text { Tammy }\end{array}$ & & \\
\hline 15. inspection & & & $\begin{array}{l}\text { Inspshn } \\
\text { inspechin } \\
\text { Betty, Kurt }\end{array}$ & $\begin{array}{l}\text { inspecchun } \\
\text { inspecsion } \\
\text { inspection } \\
\text { Mark, Tammy }\end{array}$ & \\
\hline 16. puncture & & & $\begin{array}{l}\text { Pucshr } \\
\text { pungchr } \\
\text { puncker } \\
\text { Betty }\end{array}$ & $\begin{array}{l}\text { punksher punture } \\
\text { puncture } \\
\text { Kurt, Mark, } \\
\text { Tammy }\end{array}$ & \\
\hline 17. cellar & & & $\begin{array}{l}\text { salr selr celr } \\
\text { seler } \\
\quad \text { Betty }\end{array}$ & $\begin{array}{l}\text { seler sellar celler } \\
\text { cellar } \\
\text { Kurt, Mark, } \\
\text { Tammy }\end{array}$ & \\
\hline 18. pleasure & & & $\begin{array}{l}\text { plasr plager } \\
\text { plejer pleser } \\
\text { plesher } \\
\text { Betty, Kurt, } \\
\text { Mark, } \\
\text { Tammy }\end{array}$ & plesour plesure & pleasure \\
\hline 19. squirrel & & & $\begin{array}{l}\text { scrl skwel } \\
\text { skwerl } \\
\text { Betty, Kurt }\end{array}$ & $\begin{array}{l}\text { scquril sqrarel } \\
\text { squirle squirrel } \\
\text { Mark, Tammy }\end{array}$ & \\
\hline 20. fortunate & & & $\begin{array}{l}\text { forhnat frehrit } \\
\text { foohinit } \\
\text { Betty, Kurt }\end{array}$ & $\begin{array}{l}\text { forchenut } \\
\text { fochiniate fortunet } \\
\text { Mark, Tammy }\end{array}$ & fortunate \\
\hline
\end{tabular}

